Forum Presentation

\title{
Endothelial Dysfunction in Hypertension
}

\author{
Hiroaki Shimokawa
}

The Research Institute of Angiocardiology and Cardiovascular Clinic, Kyushu University School of Medicine, Fukuoka, Japan.

\begin{abstract}
The endothelium modulates the tone of the underlying vascular smooth muscle by releasing relaxing factors, including prostacyclin, nitric oxide (NO), and endothelium-derived hyperpolarizing factor (EDHF). In most types of hypertension, endothelium-dependent relaxations are impaired because of a reduced production and/or action of endothelium-derived NO and EDHF. In essential hypertension, endothelium-dependent relaxations are reduced because of a concomitant release of vasoconstrictor prostanoids (endoperoxides and thromboxane $A_{2}$ ). These prostanoids may be produced in the vascular smooth muscle rather than in the endothelium. The endothelial dysfunction observed in hypertension is likely to be a consequence rather than a cause of the disease, representing premature aging of the blood vessels due to the chronic exposure to the high blood pressure. The endothelial dysfunction can be improved by antihypertensive therapy, favoring the prevention of the occurrence of vascular complications in hypertension. J Atheroscler Thromb, 1998 ; 4 : 118-127.
\end{abstract}

Key words: Endothelium-derived relaxing factor, Endothelium-derived contracting factor, Nitric oxide, Endothelium-derived hyperpolarizing factor

The endothelium is a monolayer of squamous cells in direct contact with the blood. Due to this anatomical position, it is a primary target for injuries such as hypertension, hyperlipidemia, diabetes mellitus and ischemia (1, 2). Since the demonstration by Furchgott and Zawadzki of the obligatory role of the endothelium in the relaxation to acetylcholine in the isolated rabbit aorta (3), it has become obvious that the endothelium modulates the degree of contraction of the underlying vascular smooth muscle. It does so by liberating several relaxing and contracting substances (Fig. 1).

The endothelium-derived relaxing factors (EDRFs) include, beside prostacyclin $\left(\mathrm{PGI}_{2}\right),(a)$ nitric oxide (NO), or closely related compound, derived from $\mathrm{L}$-arginine through the action of endothelial NO synthase (eNOS) (4),

Address for correspondence: Hiroaki Shimokawa, M.D. The Research Institute of Angiocardiology and Cardiovascular Clinic, Kyushu University School of Medicine, 3-1-1 Maidashi, Higashi-ku, Fukuoka 812-8582, Japan.

This article is presented in the Forum \#3 on Hypertension and Arteriosclerosis -A Molecular Biological Approach-at the 29th Annual Meeting on the Japan Atherosclerosis Society in Tokyo, 1997.

Received February 12, 1998. and $(b)$ endothelium-derived hyperpolarizing factor (EDHF) (5). The release of EDRF/NO by endothelial cells can be triggered by activation of cell membrane receptors, which are linked to eNOS by $\mathrm{G}$-proteins that differ depending on the agonists used $(1,6,7)$ (Fig. 2). Endothelium-derived NO (EDNO) inhibits not only contraction of the underlying vascular smooth muscle cells but also their proliferation, platelet aggregation, and adherence of blood cells (platelets and white blood cells) to the endothelium $(1,2)$ (Figs. 1 and 2). The nature of EDHF still remains uncertain, however, epoxyeicosatetraenoic acids, metabolites of P450 monooxygenase pathway of arachidonic acid, have recently been proposed as a possible candidate for EDHF (8). EDHF appears to substantially contribute to endothelium-dependent relaxations, especially in microvessels, both in animals (9) and humans (10). The endothelium-derived contracting factors (EDCFs) include superoxide anions which may act by scavenging $\mathrm{NO}$ (11), endoperoxides $\left(\mathrm{PGH}_{2}\right)$, thromboxane $\mathrm{A}_{2}$, and endothelin-1 (12) (Fig. 1). Indeed, endothelium-dependent contractions can be explained either by the production of those EDCFs, or the withdrawal of the release of EDRFs $(1,2)$.

Under several pathological conditions, endothelial cells become dysfunctional, primarily due either to a reduced 


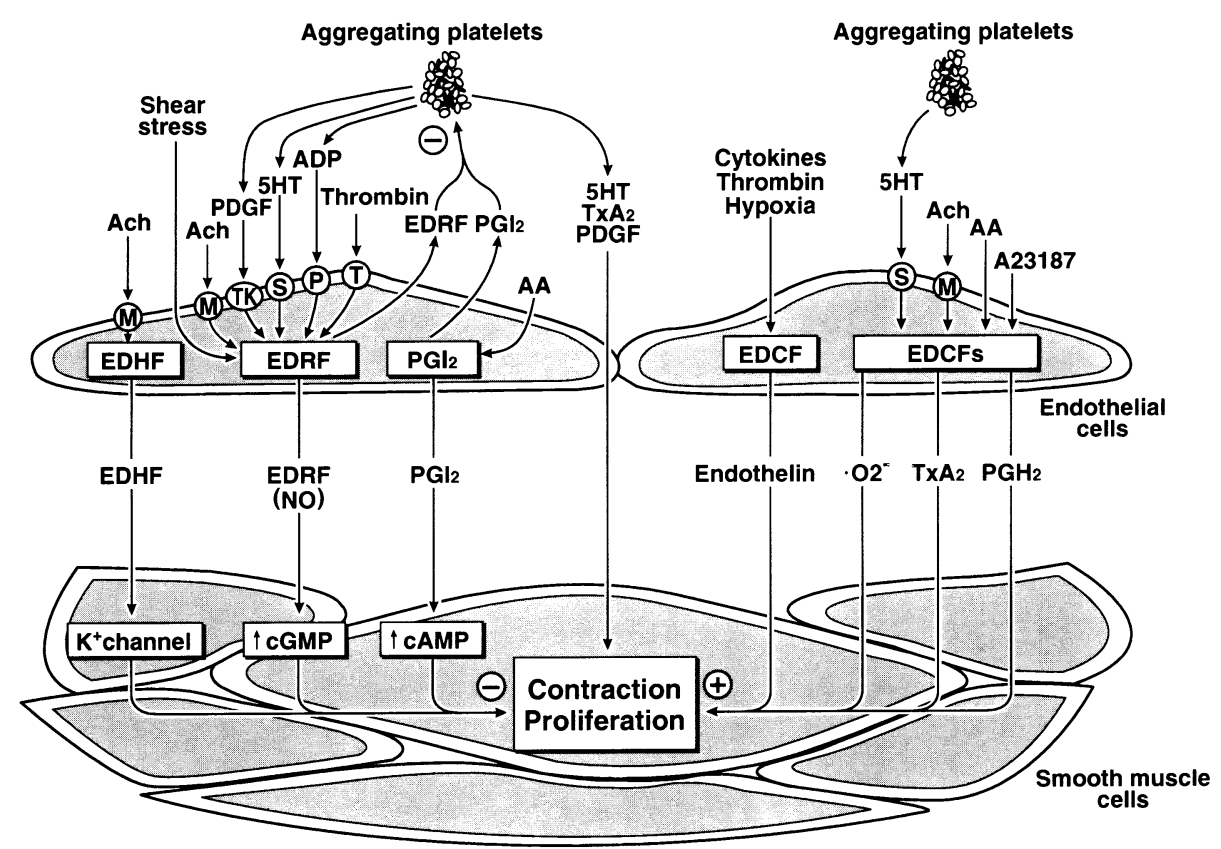

Fig. 1. Current concept of endothelial modulation of the contraction and proliferation of the underlying vascular smooth muscle. Endothelial cell synthesize and release several vasodilators and vasoconstrictors, which inhibit or stimulate the contraction and proliferation of the underlying vascular smooth muscle. Vasodilators include endothelium-derived relaxing factor (EDRF; most likely nitric oxide (NO)), prostacyclin $\left(\mathrm{PGI}_{2}\right)$, and endothelium-derived hyperpolarizing factor (EDHF). Vasoconstrictors include endothelin, superoxide anion $\left(\mathrm{O}_{2}^{-}\right)$, and prostaglandins (thromboxane $\mathrm{A}_{2}\left(\mathrm{TXA}_{2}\right)$ and prostaglandin $\left.\mathrm{H}_{2}\left(\mathrm{PGH}_{2}\right)\right)$. $A A=$ arachidonic acid; $\mathrm{Ach}=$ acetylcholine; $\mathrm{ADP}=$ adenosine diphosphate ; $\mathrm{A} 23187=$ the calcium ionophore ; $5 \mathrm{HT}=$ serotonin ; PDGF = platelet-derived growth factor ; $M=$ muscarinic receptor; $\mathrm{P}=\mathrm{P}_{2 \mathrm{Y}}$-purinergic receptor; $\mathrm{S}=$ serotonergic receptor ; $\mathrm{TK}=$ receptor for $\mathrm{PDGF}$ that is coupled to tyrosine kinase. (from Ref. (1) with permission)

production (or action) of EDRFs and/or a greater propensity to evoke endothelium-dependent contractions. This is especially the case in hypertension. This brief review summarizes the current knowledge on the endothelial dysfunction in hypertension $(1,2,13,14)$.

\section{Morphological Changes of the Endothelium}

Morphological changes of the endothelium and the subendothelial layer occurs in hypertension despite of the well-preserved integrity of the cells $(15,16)$. Endothelial cells of hypertensive blood vessels are more voluminous, bulge into the lumen and exhibit a greater variation in size, shape and orientation as compared to those of normal blood vessels $(15,16)$. The cell replication rate and number of endothelial cells is increased (17). In addition, the adherence of circulating blood cells to the endothelial cell layer is augmented $(18,19)$. The adhering cells are mainly granulocytes, monocytes and lymphocytes, and in the cerebral circulation of the rat also platelets $(18,19)$.

\section{Endothelium-Dependent Relaxations}

Endothelium-dependent relaxations to acetylcholine are reduced in the aorta of rats with spontaneous hypertension $(20,21)$, renal hypertension, salt-induced hypertension, coarctation of the aorta and DOCA salt-induced hypertension (22-25). In the spontaneously hypertensive rat $(\mathrm{SHR})$, the reduced response to acetylcholine is related to the production of a cyclooxygenase-dependent EDCF (most likely an endoperoxide) (26-28), while in most of other forms of experimental hypertension the reduced production of EDNO predominates $(1,2,13,14)$.

In mesenteric resistance arteries of the rat, EDNO accounts only in part for the endothelium-dependent relaxations to acetylcholine (9), and only part of the response is reduced in adult SHR (29). In the mesenteric artery of the SHR, endothelium-dependent relaxations to acetylcholine are impaired due to a reduced EDHFmediated response, while the EDNO-mediated component of the relaxation seems to be preserved (30).

In patients with essential hypertension, the vasodilator response to acetylcholine in the forearm is blunted (3133), although not observed in all studies (34). These results suggest that the production of EDRF/NO is impaired in hypertensive patients. The reduced dilatation to acetylcholine was not improved by the treatment with Larginine (precursor of EDNO), in one (35) but augmented in 


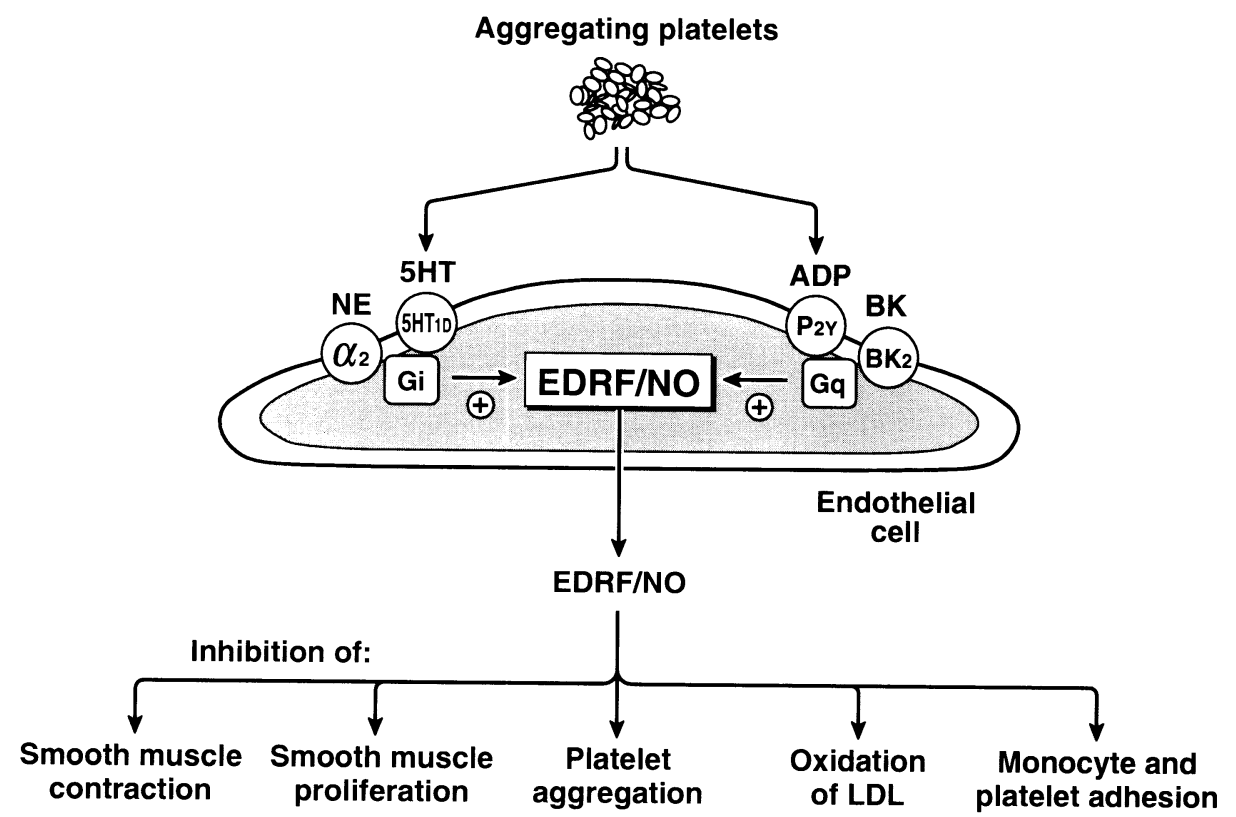

Fig. 2. Endothelial signal transduction for the synthesis of EDRF/nitric oxide (NO). There are at least two different pathways involved for the synthesis of EDRF/NO; Gi-protein-dependent and -independent ones. Endothelial $5 \mathrm{HT}_{1 \mathrm{D}}$ and $\alpha_{2}$ receptors are coupled to $\mathrm{Gi}$-protein, while $\mathrm{P}_{2 \mathrm{Y}}$ and $\mathrm{BK}_{2}$ receptors to $\mathrm{Gq}$-protein. These endothelial signal transduction systems have been documented in coronary arteries of pigs and dogs. $\mathrm{ADP}=$ adenosine diphosphate; $\mathrm{BK}=$ bradykinin ; $\mathrm{BK}_{2}=$ kininergic receptor ; $\alpha_{2}=\alpha_{2}$-adrenoceptor ; $\mathrm{CGMP}=$ cyclic guanosine monophosphate; $5 \mathrm{HT}=5$-hydroxytryptamine (serotonin); $5 \mathrm{HT}_{1 \mathrm{D}}=5 \mathrm{HT}_{1 \mathrm{D}}$-serotonergic receptor; $\mathrm{Gi}$ and $\mathrm{Gq}=\mathrm{Gi}-$ and $\mathrm{Gq}$-proteins ; $\mathrm{NE}=$ norepinephrine ; $\mathrm{P}_{2 \mathrm{Y}}=\mathrm{P}_{2 \mathrm{Y}}$-purinergic receptor. (Modified from Ref. (1) with permission)

another (36) study.

Chronic administration of $\mathrm{L}$-arginine analogues to normotensive rats results in a progressive increase in blood pressure (e.g. 37,38), and the analogues also cause peripheral vasoconstriction in nornmotensive humans (e.g. 39, 40). Thus EDNO may contribute to the overall regulation of arterial blood pressure by virtue of its ability to relax vascular smooth muscle. This interpretation is mainly based on the assumption that the effect of the NOS inhibitors is due solely mediated by the inhibition of the direct vasodilator effect of EDNO. However, this may not be the case because NO can modulate in an inhibitory fashion other factors which contribute to cardiovascular homeostasis, including the release of renin and of endothelin, the excretory function of the kidney, and the sympathetic nervous system $(1,2,13,14)$. L-arginine analogues are also known to exert non-specific cardiovascular effects which are not related to the synthesis of $\mathrm{NO}$ (e.g. 41-45). Thus it is conceivable that multiple effects other than simple inhibition of EDNO synthesis are involved when the analogues are used chronically in vivo. Mice lacking the gene for eNOS exhibits mild hypertension (46), however, genetic studies in humans do not support a linkage between eNOS and the occurrence of essential hypertension (47).

Several mechanisms may be involved in the impaired endothelium-dependent relaxations in hypertension (Fig. 3) $(1,2,13,14)$. It is likely that they all can contribute to some extent, depending on the type and stage of hypertension, the agonist tested, and the blood vessel and species of animals studied (Fig. 3) (1, 2, 13, 14). Among them, the effect of endothelial regeneration is of importance since endothelial replication rate is markedly increased in hypertension (17). Regenerating endothelial cells have an altered morphological appearance and an impaired capacity to release EDRF/NO in response to serotonin, aggregating platelets, and $\alpha_{2}$-agonist, while endothelium-dependent relaxations to bradykinin, ADP, and the calcium ionophore A23187 are well preserved (4850). The endothelium-dependent relaxations to the former agonists are pertussis toxin-sensitive, while those to the latter agonists are not. Indeed, ADP-ribosylation by pertussis toxin is reduced in regenerated endothelial cells, demonstrating the dysfunction of $\mathrm{Gi}$-protein in regenerated endothelial cells (51). The expression of endothelial $\mathrm{Gi}$-protein in human coronary arteries is reduced with aging, hypertension, and hyperlipidemia (52). Another important mechanism is a concomitant release of EDCF (26-28). Indeed, the reduced endothelium-dependent relaxations are explained best by the normal release of EDNO $(26,53)$ and the concomitant release of a cyclooxygenase-depend-ent EDCF (most likely an endoper- 


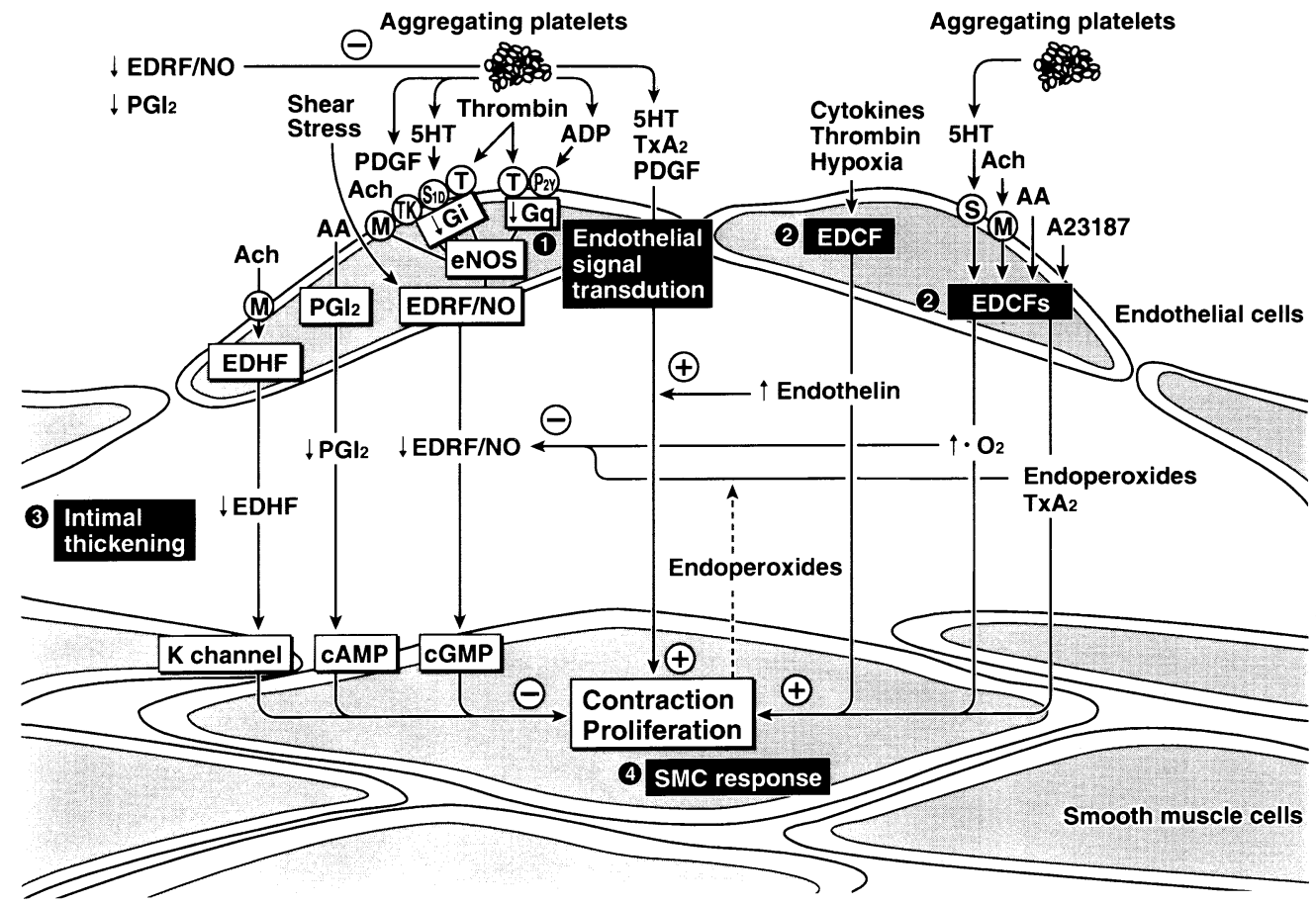

Fig. 3. Possible mechanisms underlying the reduced endothelium-dependent relaxations in hypertension. These include abnormalities in (1) endothelial signal transduction system, (2) endotheliumderived contracting factors (EDCFs), (3) intimal thickening, and (4) smooth muscle cell response. Depending on the type and stage of hypertension, vessels and species tested, and agonists used, these mechanisms may contribute to the impairments to a variable extent. Particularly, the former two mechanisms are important in the reduced endothelium-dependent relaxations in hypertension.

$\mathrm{AA}=$ arachidonic acid ; $\mathrm{Ach}=$ acetylcholine $; \mathrm{ADP}=$ adenosine diphosphate ; $\mathrm{CAMP}=\mathrm{cyclic}$ adenosine monophosphate; $\mathrm{CGMP}=$ cyclic guanosine monophosphate $\mathrm{EDHF}=$ endothelium-derived hyperpolarizing factor; $\mathrm{EDRF} / \mathrm{NO}=$ endothelium-derived relaxing factor/nitric oxide ; eNOS= endothelial nitric oxide synthase; $5 \mathrm{HT}=$ serotonin ; $\mathrm{PGI}_{2}=$ prostacyclin; $\mathrm{M}=$ muscarinic receptor ; $\mathrm{P}_{2 \mathrm{Y}}=\mathrm{P}_{2 \mathrm{Y}}$-purinergic receptor; $\mathrm{PDGF}=$ platelet-derived growth factor $; \mathrm{PGH}_{2}=$ prostaglandin $\mathrm{H}_{2} ; \mathrm{S}=$ serotonergic receptor; $T=$ thrombin receptor; $T K=$ receptor for PDGF that is coupled to tyrosine kinase; $\mathrm{TxA}_{2}=$ thromboxane $\mathrm{A}_{2}$.

oxide), with the latter scavenging the former (26-28). A reduced release of EDHF may also contribute to the impaired endothelium-dependent relaxations in hypertension, particularly in resistance vessels, where EDHF plays a more important role than in large conduit arteries under normal conditions $(9,30,54)$.

\section{Endothelium-Dependent Contractions}

In the aorta of the adult SHR, acetylcholine causes indomethacin-sensitive, endothelium-dependent contractions, which are weak or absent in normotensive WisterKyoto rats of the same age (26). Similar endotheliumdependent contractions are obtained with arachidonic acid $(55)$, serotonin $(56,57)$, endothelin $(58,59)$, and adenine nucleotides $(56,60)$. In the isolated perfused heart from normotensive rats, serotonin moderately increases coronary blood flow, while the monoamine markedly decreases flow in hearts from SHR, which can be inhibited by indomethacin (61). These results suggest that a cyclooxygenase-dependent EDCF is liberated in response to serotonin. In patients with hypertension, a cyclooxygenase-dependent vasoconstrictor mechanism participates in the blunting of endothelium-dependent vasodilation in essential hypertension but not in secondary forms of hypertension (62). The endothelial muscarinic receptors mediating the endothelium-dependent contractions to acetylcholine belong to the $M_{3}$ subtype as those initiating the release of EDRF/NO in the same preparation (63).

The endothelium-dependent contractions of the SHR aorta are augmented by inhibitors of $L$-arginine analogues and by oxyhemoglobin (which scavenges NO), but not by methylene blue (which inhibits soluble guanylate cyclase and the relaxations caused by NO) (64). This implies that EDCF released from the hypertensive endothelium interacts chemically with $\mathrm{NO}$, and both factors inactivate each other $(64,65)$. Such a chemical interaction between EDCF and NO explains the blunting of endotheliumdependent relaxations despite a normal ability of the 


\section{Normotensive (WKY) Hypertensive (SHR)}

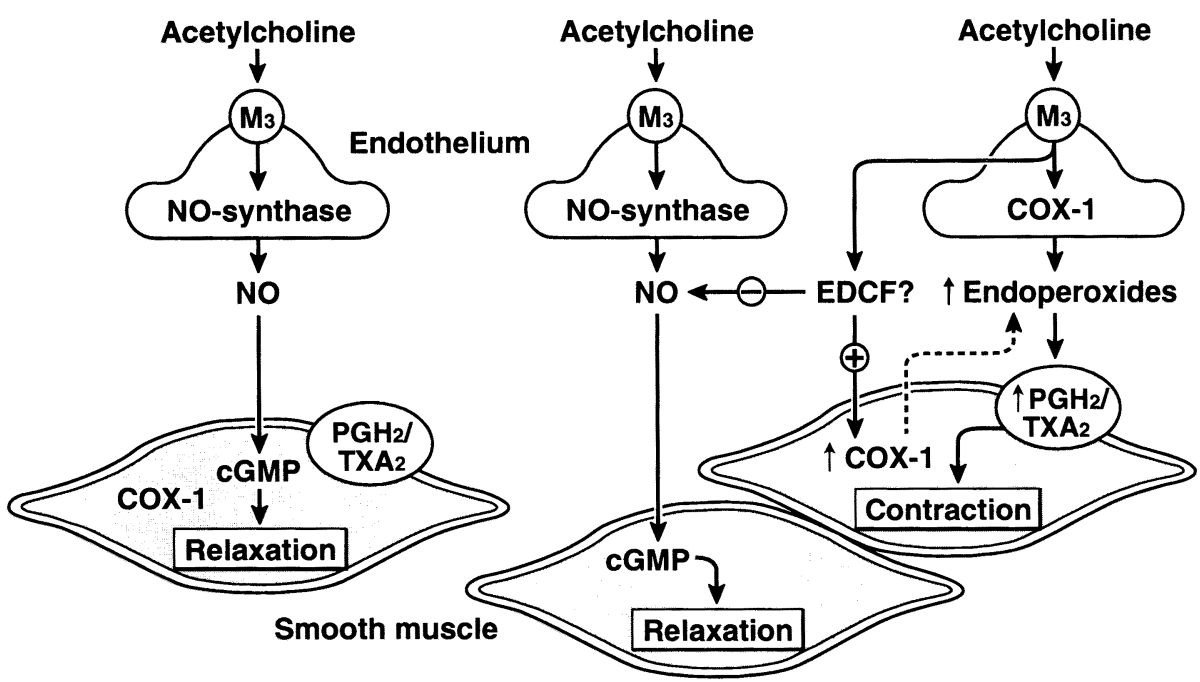

Fig. 4. Stimulation of the endoperoxide/thromboxane receptor $\left(\mathrm{PGH}_{2} / \mathrm{TxA}_{2}\right)$ is involved in endothelium-dependent contractions to acetylcholine in the aorta of spontaneously hypertensive rats (SHR). However, the nature of the substance released from the endothelium is unknown. Two possibilities are suggested; (1) endoperoxides are generated in the endothelium in response to acetylcholine, or (2) the endothelium releases an endothelium-derived contracting factor (EDCF ; possibly oxygen-derived free radicals) which stimulate the production of endoperoxides in the vascular smooth muscle. WKY = Wister-Kyoto rats; $N O=$ nitric oxide ; $C O X-1=$ cyclooxygenase-1; $c G M P=$ cyclic guanosine monophosphate; $M=$ muscarinic receptor. (From Ref. (14) with permission)

endothelial cells to release EDRF/NO in SHR $(26-28,53)$ (Fig. 4).

The endothelium-dependent contractions to several agonists in the SHR aorta are not prevented by inhibitors of thromboxane synthase, but are abolished by antagonists of endoperoxide/TxA $A_{2}$ receptors $(26-28,56-60)$. This suggests that the EDCF involved is an endoperoxide $(27,28)$. Measurement of the release of $\mathrm{PGH}_{2}$ confirmed this interpretation (66). The larger release of $\mathrm{PGH}_{2}$ in the SHR aorta may result from a greater production, as suggested by the augmented expression of cyclooxygenase (66) and/or an altered metabolism of the endoperoxide into prostanoids (67). In addition to the larger production of endoperoxides, an increased responsiveness of the hypertensive vascular smooth muscle in the SHR aorta may also contribute to the endothelium-dependent contractions (66). In the case of endothelium-dependent contractions to endothelin, the EDCF involved appears to be $\operatorname{TxA}_{2}$ (59).

The indomethacin-sensitive, endothelium-dependent contractions of the SHR aorta to acetylcholine are inhibited by a preferential inhibitor of cyclooxygenase-1 (COX1), but not by a preferential inhibitor of cyclooxygenase- 2 $(C O X-2)(66)$. These results suggest that activation of COX-1 is involved in the responses. This interpretation is further supported by the demonstration of a greater expression of COX-1, at the levels of both mRNA and protein, in the SHR aorta compared to that of normotensive rats (66). Interestingly, however, the increased expression of COX -1 in the SHR aorta is unaltered before and after endothelium removal, indicating that the increased production of endoperoxides in the hypertensive arteries may originate in the vascular smooth muscle rather than the endothelium (66). Thus, the endotheliumdependency of the response would be explained by the release of an endothelial factor, inactivated by NO, that diffuses to the underlying smooth muscle to stimulate COX-1 (14) (Fig. 4). Oxygen-derived free radicals would be likely candidates (68), since they scavenge EDRF/NO (69) and cause cyclooxygenase-dependent, endotheliumindependent contractions which are augmented in the SHR aorta (70). Indeed, free radicals have extreme short half-life, and no experiments have yet succeeded to bioassay the EDCF produced by the SHR aorta, where NO can be easily demonstrated. However, superoxide dismutase plus catalase, or deferoxamine, do not inhibit the endothelium-dependent contractions to acetylcholine in the SHR aorta (70), and superoxide dismutase does not restore endothelium-dependent vasodilatation in patients with essential hypertension (71). This suggests that free radicals other than superoxide anions or hydroxyl radicals may be involved in the responses.

Of the three members of the endothelin family, endothelin-1 (ET-1) and endothelin-3 (ET-3) circulate in the blood 
and thus are potentially important as homeostatic hormones (72). If endothelin were involved in the pathogenesis of hypertension, one would expect that the levels of the peptide are increased or that the vasoconstrictor responses to it are potentiated (1). However, the circulation levels of the peptides are not increased in rats with various types of hypertension except malignant cases of hypertension $(73,74)$. In patients with essential hypertension, the circulating levels of endothelin are modestly increased in some $(75,76)$ but not in other $(77,78)$ studies. Similarly, the changes in pressor responsiveness to endothelin with hypertension are controversial $(1,72)$. In $\mathrm{SHR}$, the increase in blood pressure and the peripheral vasoconstriction evoked by endothelin are reported to be normal (79), reduced (80) or marginally augmented (81). In isolated aorta of the SHR, the sensitivity to endothelin is enhanced (74), normal (82), or reduced (83). In addition, in heterozygous mice with deletion of the endothelin gene, the arterial blood pressure is higher, rather than lower, than in normal animals (84). Thus, there are few convincing evidence that an augmented production of, or an increased sensitivity to, endothelin contributes to the pathogenesis of most forms of hypertension $(1,72)$.

\section{Causes or Consequences?}

Several lines of evidence indicate that the reduced endothelium-dependent relaxations in hypertension are a consequence, rather than a cause, of the disease, representing premature aging of the blood vessels due to the chronic exposure to the high blood pressure. First, the reduced responses can be reversed by appropriate antihypertensive therapy $(85,86)$. Second, in hypertensive patients, the peripheral vasoconstrictor responses to $\mathrm{L}$-arginine analogues are normalized by antihypertensive therapy (87). Third, in the arteries of SHR, the endothelium-dependent relaxations to acetylcholine are normal when they are young, and thereafter progressively decreased as the arterial pressure increases with aging (88, 89). Fourth, endothelium-dependent relaxations, including those mediated by EDHF, can be reduced with aging $(1,10,90-92)$. The effect of endothelial regeneration may play an important role in this phenomenon $(1,48-50)$.

Similarly, endothelium-dependent contractions in hypertension may reflect premature aging of blood vessels due to the chronic exposure to the high blood pressure. First, in the SHR, the occurrence of endothelium-dependent contractions is age-dependent $(93,94)$. Although the responses also occur in normotensive older rats, they are more pronounced in SHR of the same age (26). Second, an indomethacin-sensitive blunting of the relaxation to acetylcholine is noted in human arteries obtained from older patients, but not in those from younger patients (95).

Thus, the altered endothelium-dependent responsiveness may not play a primary role in the initiation of hypertension. However, it could contribute to the mainte- nance of high blood pressure and facilitate the occurrence of vascular complications such as atherosclerosis $(1,2,13,14)$.

\section{Therapeutic Implications}

As mentioned above, antihypertensive therapy should be regarded as the most important strategy to treat the altered endothelium-dependent responsiveness. Besides salt restriction, body weight control, and physical therapy including exercise, the use of antihypertensive agents should be considered when the combination of these non-pharmacological therapies is not sufficient to lower blood pressure. Among the antihypertensive agents, angiotensin-converting enzyme inhibitors (ACE-I) appear to be most beneficial, since they potentiate the release of both EDNO and EDHF triggered by endogenously formed bradykinin $(96,97)$. This mechanism of action of ACE-I has an advantage in vivo since shear stress activates the local kallikrein-bradykinin system in the arterial wall, which can yield enough kinins to activate the endothelial cells to release relaxing factors, particularly when ACE is inhibited (98). Other agents that also potentiate endothelium-dependent relaxations include fish oil (eicosapentaenoic acid), antioxidants, estrogens, and L-arginine (1,99-103). In addition to those agents, calcium-channel inhibitors can inhibit endotheliumdependent contractions (104). Likewise, inhibitors of cyclooxygenase (e.g. aspirin) and antagonists of thromboxane/endoperoxide receptors (but not of thromboxane synthase) may be beneficial to prevent the occurrence of vascular complications in hypertension.

\section{Conclusion}

Endothelium-dependent relaxations are reduced in hypertension, due either to either a reduced production (or action) of EDNO/EDHF and/or a greater propensity to evoke endothelium-dependent contractions. Multiple mechanisms may be involved in the reduced responses, depending on the type of hypertension. In essential hypertension, the endothelial dysfunction is largely caused by a concomitant release of EDCF, which may be a short-lived free radical. The endothelial dysfunction in hypertension may be a consequence of the chronic exposure to high blood pressure, exhibiting premature aging of blood vessels. Antihypertensive therapy appears to improve the endothelial function and to help to prevent the occurrence of vascular complications.

Acknowledgments: The author wishes to thank Prof. Takeshita and co-workers at the Research Institute of Angiocardiology and Cardiovascular Clinic, Kyushu University School of Medicine. Original research reported in the manuscript was supported in part by the grants from the National Institute of Health of the United States, the 
American Heart Association, the Japanese Ministry of Education, Science, Sports and Culture, the Japanese Ministry of Health and Welfare, and by the grants in aids from the Sandoz Foundation for Gerontological Research, the Japan Research Foundation for Clinical Pharmacology, and the Japanese Medical Association.

\section{References}

(1) Shimokawa $\mathrm{H}$ and Vanhoutte $\mathrm{PM}$ : Endothelium and vascular injury in hypertension and atherosclerosis. In : Handbook of Hypertension. eds by Zanchetti $A$ and Mancia G, pp 1007-1068, Elsevier Science, New York, 1997

(2) Lüscher TF and Vanhoutte PM: The Endothelium; Modulator of Cardiovascular Function, pp 1-400, CRC Press, Boca Raton, 1990

(3) Furchgott RF and Zawadzki JV: The obligatory role of endothelial cells in the relaxation of arterial smooth muscle by acetylcholine. Nature, 288: 373-376, 1980

(4) Moncada S, Palmer RMJ, and Higgs EA: Nitric oxide; physiology, pathophysiology, and pharmacology. Pharmacol Rev, 43 : 109-142, 1991

(5) Feletou M and Vanhoutte PM : Endothelium-dependent hyperpolarization of canine coronary smooth muscle. Br J Pharmacol, 93 : 515-524, 1988

(6) Vanhoutte PM and Shimokawa $\mathrm{H}$ : Endothelium-derived relaxing factor(s) and coronary vasospasm. Circulation, $80: 1-9,1989$

(7) Nakaike R, Shimokawa H, Owada MK, Tokunaga O, Yasutake H, Kishimoto T, Imada C, Shiraishi T, Egashira $\mathrm{K}$, and Takeshita $\mathrm{A}$ : Vanadate causes the synthesis of endothelium-derived nitric oxide via pertussis toxin-sensitive G-protein in pigs. Am J Physiol, 271: H296H302, 1996

(8) Hecker M, Bara AT, Bauersachs J, and Busse R: Characterization of endothelium-derived hyperpolarizing factor as a cytochrome P450-derived arachidonic acids metabolite in mammals. J Physiol (Lond), 481: 407414, 1994

(9) Shimokawa H, Yasutake H, Fujii K, Owada MK, Nakaike R, Fukumoto $Y$, Takayanagi T, Nagao T, Egashira K, Fujishima $M$, and Takeshita $A$ : The importance of the hyperpolarizing mechanism increases as the vessel size decreases in endothelium-dependent relaxations in rat mesenteric circulation. J Cardiovasc Pharmacol, 28 : 703-711, 1996

(10) Urakami-Harasawa L, Shimokawa $H$, Nakashima $M$, Egashira K, and Takeshita A: Inportance of endothelium-derived hyperpolarizing factor in human arteries. J Clin Invest, 100: 2793-2799, 1997

(11) Rubanyi GM and Vanhoutte PM : Superoxide anions and hyperoxia inactivate endothelium-derived relaxing factor(s). Am J Physiol, 250: H822-H827, 1986

(12) Yanagisawa $M$, Kurihara $H$, Kimura $S$, Tomobe $Y$, Kobayashi M, Mitsui Y, Yazaki Y, Goto K, and Masaki T: A novel potent vasoconstrictor peptide produced by vascular endothelial cells. Nature, 332 : 411-415, 1988

(13) Vanhoutte PM and Boulanger CM: Endotheliumdependent responses in hypertension. Hypertens Res, 18: 87-98, 1995

(14) Vanhoutte PM : Endothelial dysfunction in hypertension.
J Hypertens, 14 (suppl 5) : S83-S93, 1996

(15) Gabbiani G, Glemes G, Guelpa C, Valloton MB, Badonnel $\mathrm{MC}$, and Huttner I: Morphologic and functional changes of the aortic intima during experimental hypertension. Am J Pathol, 96 : 399-422, 1979

(16) Limas C, Westrum B, Iwai J, and Limas CJ: Aortic morphology in salt-dependent genetic hypertention. Am J Pathol, 107 : 378-394, 1982

(17) Schwartz SM and Benditt EP: Aortic endothelial cell replication. Effects of age and hypertension. Circ Res, 41: 248-255, 1977

(18) Hazama F, Ozaki T, and Amano S : Scanning electron microscopic study of endothelial cells of cerebral arteries from spontaneously hypertensive rats. Stroke, $10: 245$ 252, 1979

(19) Chobanian AV, Brecher PI, and Haudenschild CC: Effects of hypertension and of antihypertensive therapy on atherosclerosis. Hypertension, 8 (Suppl I) : 15-21, 1986.

(20) Konishi M and Su C: Role of endothelium in dilator responses of spontaneously hypertensive rat arteries. Hypertension, 5: 881-886, 1983

(21) Winquist RJ, Bunting PB, Baskin EP, and Wallace AA : Decreased endothelium-dependent relaxation in New Zealand genetic hypertensive rats. J Hypertens, 2: 536-541, 1984

(22) Van de Voorde $\mathrm{J}$ and Leusen I: Endothelium-dependent and independent relaxation effects on aorta preparations of renal hypertensive rats. Arch Int Physiol Biochem, 92: 35-36, 1984

(23) Lüscher TF, Raij L, and Vanhoutte PM : Endotheliumdependent responses in normotensive and hypertensive Dahl rats. Hypertension, 9: 157-163, 1987

(24) Miller MJS, Pinto A, and Mullane KM : Impaired endothelium-dependent relaxations in rabbits subjected to aortic coarctation hypertension. Hypertension, 10:164-170, 1987

(25) Sim MK and Singh M: Decreased responsiveness of the aortae of hypertensive rats to acetylcholine, histamine and noradrenaline. Br J Pharmacol, 90: 147-150, 1987

(26) Lüscher TF and Vanhoutte PM : Endothelium-dependent contractions to acetylcholine in the aorta of the spontaneously hypertensive rat. Hypertension, 8: 344-348, 1986

(27) Auch-Schwelk W, Katusic ZS, and Vanhoutte PM: Thromboxane $A_{2}$ receptor antagonists inhibit endothelium-dependent contractions. Hypertension, 15:699703,1990

(28) Kato $\mathrm{T}$, Iwama $\mathrm{Y}$, Okumura $\mathrm{K}$, Hashimoto $\mathrm{H}$, Ito $\mathrm{K}$, and Satake $T$ : Prostaglandin $\mathrm{H}_{2}$ may be the endotheliumderived contracting factor released by acetylcholine in the aorta of the rat. Hypertension, 15: 475-481, 1990

(29) Dohi Y, Thiel MA, Buhler FR, and Lüscher TF : Activation of endothelial $\mathrm{L}$-arginine pathway in resistance arteries. Hypertension, 15 : 170-179, 1990

(30) Fujii K, Tomonaga M, Ohmori S, Kobayashi K, Koga I, Tanaka $Y$, and Fujishima $M$ : Decreased endotheliumdependent hyperpolarization to acetylcholine in smooth muscle of the mesenteric artery of spontaneously hypertensive rats. Circ Res, 70: 660-669, 1992

(31) Linder L, Kiowski W, Buhler FR, and Lüscher TF : Indirect evidence for release of endothelium-derived relaxing factor in human forearm circulation in vivo. Blunted 
response in essential hypertension. Circulation, 81: 1762-1767, 1990

(32) Panza JA, Ouyyumi AA, Brush JE Jr, and Epstein SE: Abnormal endothelium-dependent vascular relaxation in patients with essential hypertension. N Engl J Med, 323: 22-27, 1990

(33) Yoshida M, Imaizumi T, Ando S, Hirooka Y, Harada S, and Takeshita A: Impaired forearm vasodilatation by acetylcholine in patients with hypertension. Heart Vessels, $6: 218-223,1991$

(34) Cockcrof JR, Chowienczyk PJ, Bemjamin N, and Ritter $\mathrm{JM}$ : Preserved endothelium-dependent vasodilatation in patients with essential hypertension. N Engl J Med, 330 : 1036-1040, 1994

(35) Panza JA, Casino PR, Bader DM, and Quyyumi AA: Effect of increased availability of endothelium-derived nitric oxide precursor on endothelium-dependent vascular relaxation in normal subjects and in patients with essential hypertension. Circulation, 87: 1475-1481, 1993

(36) Imaizumi T, Hirooka $\mathrm{Y}$, Masaki H, Harada S, Momohara $M$, Tagawa $T$, and Takeshita $A$ : Effects of $L$-arginine on forearm vessels and responses to acetylcholine. Hypertension, $20: 511-517,1992$

(37) Rees DD, Palmer RM, and Moncada S: The role of endothelium-derived nitric oxide in the regulation of blood pressure. Proc Natl Acad Sci USA, 86: 3375 3378, 1989

(38) Arnal JF, Warin L, and Michel JB : Determinants of aortic cyclic guanosine monophosphate in hypertension induced by chronic inhibition of nitric oxide synthase. J Clin Invest, 90 : 647-652, 1992

(39) Vallance $\mathrm{P}$, Collier $\mathrm{J}$, and Moncada S: Effects of endothelium derived nitric oxide on peripheral arteriolar tone in man. Lancet, ii : 997-1000, 1989

(40) Haynes WG, Noon JP, Walker BR, and Webb DJ : Inhibition of nitric oxide synthesis increases blood pressure in healthy humans. J Hypertens, 11: 1375-1380, 1993

(41) Thomas G and Ramwell PW : Interaction of non-arginine compounds with the endothelium-derived relaxing factor inhibitor, $\mathrm{N}^{\mathrm{G}}$-monomethyl L-arginine. J Pharmacol Exp Ther, 260: 676-679, 1992

(42) Peterson DA, Peterson DC, Archer S, and Weir EK: The non specificity of specific nitric oxide synthase inhibitors. Biochem Biophys Res Commun, 187 : 797-801, 1992

(43) Buxton ILO, Cheek DJ, Eckman D, Westfall DP, Sanders $\mathrm{KM}$, and Keef $\mathrm{KD}: \mathrm{N}^{\mathrm{G}}$-nitro-L-arginine methyl ester and other alkyl esters of arginine are muscarinic antagonists. Circ Res, 72: 387-395, 1993

(44) Wang $\mathrm{YX}$, Poon $\mathrm{Cl}$, Poon KS, and Pang CCY : Inhibitory actions of diphenylene-iodonium on endotheliumdependent vasodilatations in vitro and in vivo. $\mathrm{Br} \mathrm{J}$ Pharmacol, 110: 1232-1238, 1993

(45) Nakaike R, Shimokawa $H$, Yasutake $H$, Sumimoto $H$, Ito A, Numaguchi K, Egashira K, Takeshige K, and Takeshita $A$ : Effects of $L$-arginine analogues on vasomotion of isolated porcine coronary arteries. Am J Physiol, 268: H1966-H1972, 1995

(46) Huang PL, Huang Z, Bloch KD, Moskowitz MA, Bevan $\mathrm{JA}$, and Fishman MC: Hypertension in mice lacking the gene for endothelial nitric oxide synthase. Nature, 377 : 239-242, 1995

(47) Bonnardeaux A, Nadaud S, Charru A, Jeunemaitre X,
Corvol P, and Soubrier F : Lack of evidence for linkage of the endothelial cell nitric oxide synthase gene to essential hypertension. Circulation, 91: 96-102, 1995

(48) Shimokawa H, Aarhus LL, and Vanhoutte PM: Porcine coronary arteries with regenerated endothelium have a reduced endothelium-dependent responsiveness to aggregating platelets and serotonin. Circ Res, 61: 256270,1987

(49) Shimokawa H, Flavahan NA, and Vanhoutte PM : Natural course of the impairment of endothelium-dependent relaxations after balloon endothelium-removal in porcine coronary arteries. Circ Res, 65: 740-753, 1989

(50) Shimokawa H, Flavahan NA, and Vanhoutte PM: Angiographic demonstration of hyperconstriction induced by serotonin and aggregating platelets in porcine coronary arteries with regenerated endothelium. J Am Coll Cardiol, 17 : 1197-1202, 1991

(51) Shibano T, Codina J, Birmbauer L, and Vanhoutte PM: Pertussis toxin-sensitive G-proteins in regenerated endothelial cells. Am J Physiol, 267 : H979-H981, 1994

(52) Tsutsui M, Shimokawa H, Tanaka S, Kuwaoka I, Hase K, Nogami N, Nakanishi K, and Okamatsu S: Endothelial Gi protein in human coronary arteries. Eur Heart J, 15: 1261-1266, 1994

(53) Sawada $Y$, Sakamaki T, Nakamura T, Sato K, Ono Z, and Murata K: Release of nitric oxide in response to acetylcholine is unaltered in spontaneously hypertensive rats. J Hypertens, 12 : 745-750, 1994

(54) Van de Voorde J, Vanheel B, and Leusen I: Endothelium-dependent relaxation and hyperpolarization in aorta from control and renal hypertensive rats. Circ Res, 70 : 1-8, 1992

(55) Boulanger CM and Vanhoutte PM : Interleukin-2 causes endothelium-dependent contractions to arachidonic acid. Hypertension, 21: 289-293, 1993

(56) Lüscher TF and Vanhoutte PM : Endothelium-dependent responses to platelets and serotonin in spontaneously hypertensive rats. Hypertension, 8 (suppl II) : II55-II60, 1986

(57) Auch-Schwelk W and Vanhoutte PM : Endothelium-derived contracting factor released by serotonin in the aorta of the SHR. Am J Hypertens, 4: 769-772, 1991

(58) Auch-Schwelk W and Vanhoutte PM: Contractions to endothelin in normotensive and spontaneoulsy hypertensive rats: role of endothelium and prostaglandins. Blood Press, 1: 45-49, 1992

(59) Taddei S and Vanhoutte PM: Role of endothelium in endothelin-evoked contractions in the rat aorta. Hypertension, 21: 9-15, 1993

(60) Mombouli JV and Vanhoutte PM : Purinergic endothelium-dependent and independent contractions in rat aorta. Hypertension, 22 : 577-583, 1993

(61) Lüscher TF, Rubanyi GM, Aarhus LL, Edoute Y, and Vanhoutte PM: Serotonin reduces coronary flow in the isolated heart of the spontaneously hypertensive rat. $\mathrm{J}$ Hypertens, 4 (suppl 5) : S148-S150, 1986

(62) Taddei S, Virdis A, Mattei P, and Salvetti A : Vasodilation to acetylcholine in primary and secondary forms of human hypertension. Hypertension, 21: 929-933, 1993

(63) Boulanger CM, Morrison KJ, and Vanhoutte PM : Mediation by $\mathrm{M}_{3}$-muscarinic receptors mediate both endothelium-dependent contraction and relaxation to acetylcholine in the aorta of the spontaneously hypertensive 
rat. $\mathrm{Br} J$ Pharmacol, 112 : 519-524, 1994

(64) Auch-Scwelk W, Katusic ZS, and Vanhoutte PM: Nitric oxide inactivates endothelium-derived contracting factor in the rat aorta. Hypertension, 19: 442-445, 1992

(65) Ito T, Kato T, Iwama $Y$, Muramatsu M, Shimizu K, Asano $\mathrm{H}$, Okumura K, Hashimoto $\mathrm{H}$, and Satake T : Prostaglandin $\mathrm{H}_{2}$ as an endothelium-derived contracting factor and its interaction with endothelium-derived nitric oxide. $J$ Hypertens, 9: 729-736, 1991

(66) Ge T, Hughes H, Junquero DC, Wu KK, Vanhoutte PM, and Boulanger $\mathrm{CM}$ : Endothelium-dependent contractions are associated with both augmented expression of prostaglandin $\mathrm{H}$ synthase-1 and hypersensitivity to prostaglandin $\mathrm{H}_{2}$ in the SHR aorta. Circ Res, 76: 10031010, 1995

(67) Lin L, Balazy M, Pagano PJ, and Nasjletti A : Expression of prostaglandin $\mathrm{H}_{2}$-mediated mechanism of vascular contraction in hypertensive rats: relation to lipoxygenase and prostacyclin synthase activities. Circ Res, 74: 197-205, 1994

(68) Vanhoutte PM and Katusic ZS: Endothelium-derived contracting factor: endothelium and/or superoxide anion? Trends Pharmacol Sci, 9: 229-230, 1988

(69) Rubanyi GM and Vanhoutte PM : Superoxide anions and hyperoxia inactivate endothelium-derived relaxing factor(s). Am J Physiol, 250: H822-H827, 1986

(70) Auch-Schwelk W, Katusic ZS, and Vanhoutte PM: Contractions to oxygen-derived free radicals are augmented in aorta of the spontaneously hypertensive rat. Hypertension, $13:$ 859-864, 1989

(71) Garcia CE, Kilcoyne CM, Cardilo C, Cannon RO III, Ouyyumi AA, and Panza JA: Effect of copper-zinc superoxide dismutase on endothelium-dependent vasodilation in patients with essential hypertension. Hypertension, 26: 863-868, 1995

(72) Vanhoutte PM: Is endothelin involved in the pathogenesis of hypertension? Hypertension, 21: 747-751, 1993

(73) Suzuki N, Miyauchi T, Tomobe Y, Matsumoto H, Goto K, Masaki $\mathrm{T}$, and Fujino $\mathrm{M}$ : Plasma concentrations of endothelin-1 in spontaneously hypertensive rats and DOCA-salt hypertensive rats. Biochem Biophys Res Commun, 167 : 941-947, 1990

(74) Vemulapalli S, Chiu PJS, Rivelli M, Foster CJ, and Sybertz EJ: Modulation of circulating endothelin levels in hypertension and endotoxemia in rats. J Cardiovasc Pharmacol, 18: 895-903, 1991

(75) Kohno M, Yasunari K, Murakawa KI, Yokokawa K, Horio $\mathrm{T}$, Fukui $\mathrm{T}$, and Takeda $\mathrm{T}$ : Plasma immunoreactive endothelin in essential hypertension. $A m \mathrm{~J}$ Med, 88: 614-618, 1990

(76) Saito Y, Nakao K, Mukoyama M, and Imura H : Increased plasma endothelin level in patients with essential hypertension. N Engl J Med, 322: 205, 1990

(77) Davenport AP, Ashby MJ, Easton P, Ella S, Bedford J, Dickerson C, Nunez DJ, Capper SJ, and Brown MJ : A sensitive radioimmunoassay measuring endothelin-like immunoreactivity in human plasma: Comparison of levels in patients with essential hypertension and normotensive control subjects. Clin Sci, 78: 261-264, 1990

(78) Schiffrin EL and Thibault G: Plasma endothelin in human essential hypertension. Am J Hypertens, 4: 303-308, 1991
(79) Hirata Y, Matsuoka H, Kimura K, Fukui K, Hayakawa H, Suzuki E, Sugimoto T, Yanagisawa M, and Masaki T: Renal vasoconstriction by the endothelial cell-derived peptide endothelin in spontaneously hypertensive rats. Circ Res, 65 : 1370-1379, 1989

(80) Winquist RJ, Bunting PB, Garsky VM, Lumman PK, and Schofield TL: Prominent depressor response to endothelin in spontaneously hypertensive rats. Eur $\mathrm{J}$ Pharmacol, 163: 199-203, 1989

(81) Miyauchi T, Ishikawa $T$, Tomobe $Y$, Yanagisawa $M$, Kimura S, Sugishita Y, Ito I, Goto K, and Masaki T: Characteristics of pressor response to endothelin in spontaneously hypertensive and Wister-Kyoto rats. Hypertension, $14:$ 427-434, 1989

(82) Auch-Scwelk W and Vanhoutte PM: Contractions to endothelin in normotensive and spontaneously hypertensive rats: Role of endothelium and prostaglandins. Blood Press, 1: 45-49, 1992

(83) Dohi $Y$ and Lüscher TF : Endothelin in hypertensive resistance arteries. Hypertension, 18: 543-549, 1991

(84) Kurihara $Y$, Kurihara H, Suzuki H, Kodama T, Maemura K, Nagai R, Oda H, Kuwaki T, Cao W-H, Kamada N, Jishage K, Oucho Y, Azuma S, Toyoda Y, Ishikawa T, Kumada M, and Yazaki $Y$ : Elevated blood pressure and craniofacial abnormalities in mice deficient in endothelin-1. Nature, 368: 693-694, 1994

(85) Lüscher TF, Vanhoutte PM, and Raij L : Antihypertensive treatment normalizes decreased endothelium-dependent relaxations in salt-induced hypertension of the rat. Hypertension, 9 (suppl III) : III193-III197, 1987

(86) Takase H, Moreau P, Kung CF, Nava E, and Lüscher TF : Antihypertensive therapy prevents endothelial dysfunction in chronic nitric oxide deficiency. Effect of verapamil and trandolapril. Hypertension, $27: 25-31,1996$

(87) Lyons D, Webster J, and Benjamen N: The effect of antihypertensive therapy on responsiveness to local intra-arterial $\mathrm{N}^{\mathrm{G}}$-monomethyl-L-arginine in patients with essential hypertension. J Hypertens, 12: 1047-1052, 1994

(88) Gray SD and De Mey JG : Vascular reactivity in neonatal spontaneously hypertensive rats. Prog Appl Microcirc, 8: 173-180, 1985

(89) Dohi Y, Thiel M, Bühler FR, and Lüscher TF : Activation of endothelial L-arginine pathway in resistance arteries: effect of age and hypertension. Hypertension, 15: 170179,1990

(90) Gerhard M, Roddy M-A, Creager SJ, and Creager MA : Aging progressively impairs endothelium-dependent vasodilation in forearm resistance vessels of humans. Hypertension, $27:$ 849-853, 1996

(91) Fujii K, Ohmori S, Tominaga M, Abe I, Takata Y, Ohya Y, Kobayashi $\mathrm{K}$, and Fujishima $\mathrm{M}$ : Age-related changes in endothelium-dependent hyperpolarization in the rat mesenteric artery. Am J Physiol, 265: H509-H516, 1993

(92) Nakashima $M$ and Vanhoutte PM: Age-dependent decrease in endothelium-dependent hyperpolarization to endothelin-3 in the rat mesenteric artery. J Cardiovasc Pharmacol, 22 (suppl 8) : S352-S354, 1993

(93) Koga T, Tanaka U, Kobayashi K, Takishita S, Yamashita $Y$, and Fujishima $M$ : Age and hypertension promote endothelium-dependent contractions to acetylcholine in the aorta of the rat. Hypertension, 14: 542-548, 1989

(94) Lang MG, Noll G, and Lüscher TF : Effect of aging and 
hyperpolarization on contractility of resistance arteries : modulation by endothelial factors. Am J Physiol, 269 : H837-H844, 1995

(95) Lüscher TF, Cooke JP, Houston DS, Neves RJ, and Vanhoutte PM: Endothelium-dependent relaxations in human arteries. Mayo Clinic Proc, 62 : 601-606, 1987

(96) Vanhoutte PM, Auch-Scwelk W, Biondi ML, Lorenz RR, Schini VB, and Vidal MJ: Why are converting enzyme inhibitors vasodilators? Br J Clin Pharmacol, 28 : 95S104S, 1989

(97) Mombouli J-V, Illiano S, Nagao T, Scott-Burden T, and Vanhoutte PM: Potentiation of endothelium-dependent relaxations to bradykinin by angiotensin I converting enzyme inhibitors in canine coronary artery involves both endothelium-derived relaxing and hyperpolarizing factor. Circ Res, 71: 137-144, 1992

(98) Mombouli JV and Vanhoutte PM : Kinins and endothelial control of vascular smooth muscle. Annu Rev Pharmacol Toxicol, 35 : 679-705, 1995

(99) Shimokawa H, Lam JYT, Chesebro JH, Bowie EJW, and Vanhoutte PM: Effects of dietary supplementation with cod-liver oil on endothelium-dependent responses in porcine coronary arteries. Circulation, 76: 898-905,
1987

(100) Shimokawa $\mathrm{H}$ and Vanhoutte PM : Dietary w3 fatty acids and endothelium-dependent relaxations in porcine coronary arteries. Am J Physiol, 256: H968-H973, 1989

(101) Shimokawa H, Aarhus LL, and Vanhoutte PM: Dietary omega-3 polyunsaturated fatty acids augment endothelium-dependent relaxation to bradykinin in porcine coronary microvessels. Br J Pharmacol, 95 : 1191-1196, 1989

(102) Shimokawa H and Vanhoutte PM: Dietary cod-liver oil improves endothelium-dependent responses in hypercholesterolemic and atherosclerotic porcine coronary arteries. Circulation, 78: 1421-1430, 1988

(103) Tagawa H, Shimokawa H, Tagawa T, Kuroiwa-Matsumoto $M$, Hirooka $Y$, and Takeshita A: Short-term estrogen augments both nitric oxide-mediated and nonnitric oxide-mediated endothelium-dependent forearm vasodilation in postmenopausal women. J Cardiovasc Pharmacol, 30 : 481-488, 1997

(104) Vanhoutte PM : Vascular endothelium and $\mathrm{Ca}^{2+}$ antagonists. J Cardiovasc Pharmacol, 12 (Suppl 6) : S21-S28, 1988 